\title{
SITUS PRINGGOLOYO, SEBUAH DATA PENINGGALAN MEGALITIK DI DAERAH WEDI, KLATEN, JAWA TENGAH
}

Oleh: Gunadi

\section{PENDAHULUAN}

Pringgoloyo atau sering disebut Pringgolayan merupakan sebutan bagi sebuah tempat dan bukan merupakaı nama dukuh ataupun kampung. Sebutan tersebut didasarkan pada temuan susunan batu berbentuk setengah lingkaran yang dikeramatkan oleh penduduk di sekitarnya. Selanjutnya nama Pringgolayan dalam tulisan ini diguna. kan untuk menyebut sebuah situs megalitik. Secara administratif situs Pringgoloyo terletak di dukuh Sukorejo, kelurahan Sukorejo. kecamatan Wedi, kabupaten Klaten, tepatnya 6 kilometer di sebelah Selatan kota Klaten. Belum diketahui alasan penyebutan situs tersebut sebagai Pringgoloyo atau Pringgolayan.

Menurut cerita masyarakat setempat, dahulu lokasi tersebut merupakan daerah yang sangat keramat dan angker. Masyarakat sekitar tempat tersebut percaya bahwa situs Pringgoloyo merupakan tempat tinggal Raden Bagus Munyul yang mempunyai klangenan harimau putih tan kuda putih. Sampai saat ini suara gemerincing kuda putih masih sering didengar penduduk pada waktu-waktu tertentu di malam hari. Dikatakan pula bahwa situs Pringgoloyo terletak pada sebuah desa yang berbentuk macak sili, yang berarti bentuknya mirip dengan ikan sili (jenis ikan sungai). Peninggalan tersebut di atas terletak di ujung barat desa. Menurut kepercayaan masyarakat setempat, bentuk desa seperti di atas menunjukkan atau merupakan tanda bahwa daerah tersebut angker. Tidak dike tahui bilamana situs tersebut mulai dihuni dan menjadi sebuah kam pung. 
Selain susunan batu yang berbentuk mirip setengah lingkaran. ditemukan pula sepasang batu pipisan dan gandik. Sampai saat ini masih banyak orang yang datang ke tempat tersebut untuk memohon keselamatan, banyak rejeki. dan perlindungan. Berdasarkan data-data tersebut di atas, ditemukan beberapa hal yang menarik, antara lain kepercayaan masyarakat setempat terhadap susunan batu tersebut dan bentuk kampung yang juga mempunyai latar belakang tertentu. yang keduanya berhubungan dengan peninggalan megalitik. Sampai saat ini situs Pringgoloyo belum pernah dibicarakan, oleh karena itu pada kesempatan ini penulis akan mencoba menyajikan data tentang peninggalan megalitik tersebut.

\section{URAIAN TEMUAN}

Sebelum membicarakan temuan pada situs megalitik Pringgo loyo, akan diuraikan jenis-jenis teınuan megalitik di Indonesia. Kla sifikasi benda megalitik telah dilakukan oleh Dr. A.N.J. Th. A. Th. van der Hoop sebagai berikut: (van der Hoop. 1932: 66-149)

1. Stone image (aRca batu)

2. Lesung batu (lumpang batu)

3. Upright stone (Menhir)

4. Stone avenues (jalan-jalan batu)

5 Tetraliths (kelompok batu empat)

6. Dolmen

7. Stone cist (peti kubur batu)

8. Terrace grave (kubur teras berundak)

9. Pit marked stone (batu dakon)

Apabila temuan dari situs Pringgoloyo dikaitkan dengan hasil klasifikasi van der Hoop, maka kedua jenis temuan dari situs Pring goloyo tidak termasuk ke dalam klasifikasi tersebut. Walaupun demikian dapat diperkirakan bahwa peninggalan yang ditemukan di situs Pringgoloyo merupakan peninggalan megalitik. Seperti dikatakan oleh Frits A. Wagner, bahwa pengertian megalitik tidak selalu harus 
dihubungkan dengan batu-batu besar, sebab batasan "batu-batu besar" tersebut dapat mengarah kepada konsep yang keliru. Monumen dari batu-batu kecil dapat pula dimasukkan dalam klasifikasi megalitik, apabila hal tersebut dimaksudkan untuk tujuan sakral (Wagner, 1959: 23-24).

Di atas telah disebutkan bahwa temuan pada situs Pringgoloyo dapat dibedakan menjadi dua jenis, yakni susunan batu berbentuk setengah lingkaran serta sepasang batu pipisan dan gandik. Kedua jenis temuan tersebut akan diuraikan sebagai berikut:

\section{A. Susunan batu setengoh lingkaran}

Susunan ini terdiri dari tujuh buah batu, lima buah di antaranya masih terlihat in situ dan dua buah kemungkinan sudah tidak in situ. Pada tahun 1977, sewaktu penulis mengadakan inventarisasi ulang bersama Sdr. Joko Tiarso, susunan batu tersebut masih tampak jelas dan belum banyak tertimbun tanah. Pada peninjauan berikutnya, yaitu tanggal 7 Mei 1985 yang lalu, tampak bahwa susunan batu tersebut mengalami perubahan, yakni sebagian batu-batunya tertimbun tanah. Susunan batu di atas dengan arah Utara - Selatan dan bagian yang cembung pada sisi sebelah Barat, terletak di pekarangan Yososumarto, yaitu tepat di ujung kampung Sukorejo. Susunan batu setengah lingkaran di atas terdiri dari tujuh buah batu wungkul (utuh) dengan ukuran sebagai berikut:

$$
\begin{aligned}
& \text { batu } 1 \varnothing=50 \mathrm{~cm} \\
& \text { batu } 2 \varnothing=80 \mathrm{~cm} \\
& \text { batu } 3 \varnothing=100 \mathrm{~cm} \\
& \text { batu } 4 \varnothing=80 \mathrm{~cm} \\
& \text { batu } 5 \emptyset=80 \mathrm{~cm} \\
& \text { batu } 6 \varnothing=70 \mathrm{~cm} \\
& \text { batu } 7 \varnothing=60 \mathrm{~cm}
\end{aligned}
$$

Selain tujuh buah batu tersebut, ditemukan pula sebuah batu berbentuk segi empat, kemungkinan sebuah batu pipisan yang terbalik dan tertimbun tanah. 


\section{B. Batu pipisan dan gandik}

Sepasang batu pipisan dan gandik ditemukan di kompleks susunan batu setengah lingkaran. Pada saat ini sepasang batu pipis an dan gandik tersebut sudah tidak dijumpai kembali. Menurut ke terangan Yososumarto, pipisan dan gandik di atas kem ungkinan ter timbun tanah sewaktu ia mengurug lokasi sekitar susunan batu tersebut untuk kepentingan para pengunjung yang bermalam di tempat itu. Ukuran batu pipisan dan gandik yang berhasil diukur pada tahun 1977 adalah sebagai berikut:
a. batu pipisan: panjang bidang atas $=38 \mathrm{~cm}$
lebar bidang atas $=25 \mathrm{~cm}$
panjang bidang bawah $=13 \mathrm{~cm}$
lebar bidang bawah $=13 \mathrm{~cm}$
tinggi
$-15 \mathrm{~cm}$
b. batu gandik : panjang
$=22 \mathrm{~cm}$
garis tengah
$=6,5 \mathrm{~cm}$

Tanda-tanda pada permukaan bidang atas batu pipisan tersebut menunjukkan kemungkinan penggunaannya. Penggunaan batu pipis an dan gandik sampai saat ini masih dapat dilihat pada masyara kat daerah kabupaten Klaten pada khususnya dan daerah Yogyakarta dan Surakarta pada umumnya.

\section{PEMBAHASAN DAN KESIMPULAN}

Pengertian umum tentang tradisi megalitik adalah suatu tradisi yang menggunakan batu besar, berasal dari masa prasejarah, dan berlatar belakang pemujaan kepada roh nenek moyang (Teguh Asmar, 1974: 19). Kenyataan tersebut di atas antara lain ditemukan di situs-situs megalitik di daerah Eropa Barat, misalnya di Skandinavia dan Inggris bagian Selatan (Adamson Hoebel, 1958: 101105). Di Indonesia sering terjadi penyimpangan, antara lain monu. men megalitik banyak didirikan tanpa menggunakan batu besar dan bahan yang digunakan tidak selalu berupa batu utuh. 
Pendirian bangunan megalitik oleh para pendukungnya dimaksudkan sebagai lambang dalam upacara ritual. Upacara-upacara ritual tersebut tidak selalu bertujuan pemujaan kepada roh nenek moyang. Hal ini antara lain dibuktikan pada batu-batu melingkar yang ditemukan tersebar di daerah antara Cumberland, Cornwall yang oleh A.L. Lewis dihubungkan dengan penanggalan yang menggunakan patokan matahari. Ada pula teori-teori yang mengatakan tentang hubungan stone henge dengan dua belas tanda bintang/zodiac (Francis Hitching, 1976: 66-70). Di Indonesia kasus yang menyerupai contoh-contoh di atas telah ditulis oleh vander Hoop dalam Megalithic Remains In South Sumatra, yaitu bahwa menhir yang diternukan di bukit Pipi Podo dapat dihubungkan dengan posisi matahari dan untuk mengetahui bila musim tanam harus dimulai (van der Hoop, 1932: 115).

Di atas telah disebutkan bahwa menurut cerita masyarakat setempat situs Pringgoloyo dahulu merupakan tanah kosong dan kera. mat. Kata Pringgoloyo saat sekarang bukan merupakan nama kam. pung, tetapi nama lain untuk menyebut daerah tempat ditemukannya susunan batu melingkar. Nama Pringgoloyo di atas tidak ada hubungannya dengan patih Sunan Pakubuwono III, seperti yang disebut sebut dalam babad Giyanti. Secara etimologis Pringgoloyo berasal dari kata pringgo yang berarti kedudukan dan loyo yang berarti mati (Mardiwarsito, 1981). Situs di atas kemungkinan dapat dihubungkan dengan penguburan, sebab bentuk susunan setengah lingkaran tersebut kemungkinan dahulu berbentuk sebuah lingkaran. Oleh karena adanya proses alam atau kegiatan manusia, maka susunannya berubah dan batu-batunya sebagian hilang. Bentuk kubur semacam itu banyak ditemukan di situs Watu Kandang, Matesih (Soejono, 1977: 198 - 211). Bentuk kampung yang sekarang dikatakan oleh masyarakat sebagai macak sili, denahnya berbentuk seperti perahu. Pada masyarakat prasejarah, perahu sering diasosiasikan sebagai wahana bagi roh seorang yang menuju ke alam baka. Hal tersebut diperkuat oleh Stutterheim yang mengatakan bahwa pada masyarakat Indonesia terdapat suatu kecenderungan untuk menempatkan roh 
di tempal-tempat yang tidak dihuni manusia dan sukar dicapai. Un tuk masyarakat pulau kecil, tempat yang dimaksud terletak di pulau tetangga yang tidak dikenal serta ditakuti (Stutterheim, 1931: 13)

Dikatakan pula oleh masyarakat setempat bahwa bentuk kam. pung Sukorejo yang macak sili tersebut merupakan tanda atau ciri sebuah kampung yang angker. Bentuk tersebut jelas disengaja oleh masyarakat pendukungnya, sebab faktor-faktor lain yang mengharus. kan seperti misalnya kondisi geografis, tidak dijumpai di lokasi tersebut. Atas dasar data di atas. jelas bahwa kampung Sukorejo adalah kampung kuno, sebab kampung atau desa sekarang memiliki syarat syarat lain sesuai dengan kebutuhan masyarakat yang berlaku saat ini. Apabila peninggalan di situs Pringgoloyo dihubungkan dengan ter jadinya kampung tersebut. maka kemungkinan batu-batu yang her bentuk setengah lingkaran di atas dimaksudkan sebagai lambang atau peringatan pendiriannya. Pada masyarakat di Pulau Sawu. sebuah batu yang terletak di puncak gunung Kolo Teriwu tidak hanya merupakan tanda atau lambang suatu daerah, bahkan goresan-gores an yang terdapat pada batu tersebut dijadikan dasar untuk membagi pulau Sawu menjadi tiga bagian wilayah (Nico L. Kana. 1983: $120-1221$

Hingga saat ini sebagian masyarakat masih menganggap bahwa susunan batu yang berbentuk setengah lingkaran tersebut adalah tem. pat bersemayam Raden Bagus Munyul. yaitu tokoh alam gaib yang mempunyai kekuatan supernatural. Sampai sekarang masih terdapat pula beberapa orang yang datang ke tempat tersebut untuk memohon pertolongan kepada tokoh di atas, agar cepat mendapat rejeki, naik pangkat, dan sebagainya. Bahkan ada pula yang memohon pertolongan mencarikan seorang yang hilang atau pergi di tempat yang jauh. Syarat yang harus dipenuhi apabila akan memohon pertolongan ialah membawa rokok, telur ayam jawa, kembang wangi, uang wajib, dan kemenyan. Setelah permohonannya berhasil, mereka harus caos dahar berupa nasi gurih dan ingkung ayam jantan beserta uba rampe. 
Kebiasaan seperti di atas dijumpai pula di situs-situs megalitik yang tersebar di daerah Cilongok, Banyumas (Gunadi, 1983: 7-11).

Peninggalan berupa batu pipisan dan gandik sampai sekarang masih banyak digunakan oleh masyarakat, terutama untuk membuat obat tradisional. Menurut kepercayaan setempat, tidak sembarang orang boleh menggunakannya. Biasanya yang membuat obat tersebut umurnya lebih tua dan tidak boleh mengenakan baju, tetapi hanya mengenakan pakaian pinjungan. Dari pengamatan penulis yang dilakukan di daerah Wedi, kabupaten Klaten, ternyata pipisan yang lebih kuna lebih sering digunakan, sebab mereka yakin bahwa pipisan tersebut masih mempunyai tuah, sehingga dapat mempengaruhi kemanjuran obat yang dibuat dengan menggunakan pipisan tersebut. Berdasarkan analogi etnografis di atas, dapat dikatakan bahwa sepasang batu pipisan dan gandik yang terdapat di situs Pringgoloyo tersebut kemungkinan merupakan peralatan untuk membuat obat tradisional yang digunakan oleh masyarakat di sekitar situs tersebut. Bentuk dan ukuran batu pipisan dan gandik bervariasi. Pada kesempatan ini penulis tidak akan membahas lebih lanjut tentang variabel tersebut. Sebagai kesimpulan sementara dapat diutarakan bahwa fungsi pipisan dan gandik adalah sebagai alat membuat obat tradisional (jamu). Alat di atas sampai sekarang sering dihubungkan dengan nenek moyang, sebab banyak pipisan dan gandik yang diperoleh turun temurun. Di samping itu masyarakat Jawa Tengah pada umum nya percaya bahwa tidak setiap orang boleh memiliki alat tersebut. sebelum memenuhi persyaratan.

Atas dasar uraian di atas, maka dapat disimpulkan bahwa situs Pringgoloyo merupakan situs dengan peninggalan megalitik. Beberapa kemungkinan mengenai fungsi peninggalan tersebut antara lain adalah sebagai situs penguburan atau sebagai lambang terjadinya kampung/pemukiman di tempat tersebut. Anggapan dan kepercayaan masyarakat setempat terhadap situs tersebut sampai sekarang masih menunjukkan adanya hubungan antara manusia dengan tokoh di alam gaib. Hal ini merupakan salah satu ciri tradisi megalitik yang masih berlangsung di tempat tersebut

Berkala Arkeologi VII (2) 


\section{DAFTAR BACAAN}

Adamson Hoebel, W., 1958. Man in the Primitive World. Second Edition. McGraw Hill Book Company, New York London-Toronto.

Francis Hitching. 1976. Earth Magic. Cossell \& Company Limited, London.

Fritz A. Wagner, 1959. "Indonesia The Art of an Island Group". Art of the World Series. Methuen, London.

Gunadi, 1983. Tradisi Megalitik di daerah Cilongok. Tesis Fakultas Sastra Universitas Gajah Mada. Yogyakarta.

Hoop, A.N.J. van der, 1832. Megalithic Remains in South Sumatra. Zutphen W.J. Thieme \& Oie, Translated by William Shirlaw.

Mardiwarsito, L. 1981. Kamus Jawa Kuno, Nusa Indah. Percetakan Arnoldus, Ende-Flores.

Nico L. Kana, 1983. Dunia Orang Sawu. Seri Budi No. 2, Sinar Harapan. Jakarta.

Soejono, R.P. (Editor), 1977. "Jaman Prasejarah di Indonesia", Sejarah Nasional Indonesia I. Balai Pustaka, Jakarta.

Soekanto, 1952. Sekitar Yogyakarta 1755-1825, Mahabarata, JakartaAmsterdam.

Stutterheim, W.F., "The Meaning of the Hindu Javanese Candi". Journal of American Oriental Society. Vol. 51 No. 1

Teguh Asmar, "Pengetahuan masa Kini tentang Prasejarah Sulawesi Utara". Bulletin Yapema, Th. 1 No. 1.

Teguh Asmar, Laporan Her-Inventarisasi daerah Kab. Klaten. Suaka Peninggalan Sejarah dan Purbakala Jawa Tengah. tidak diterbitkan. 


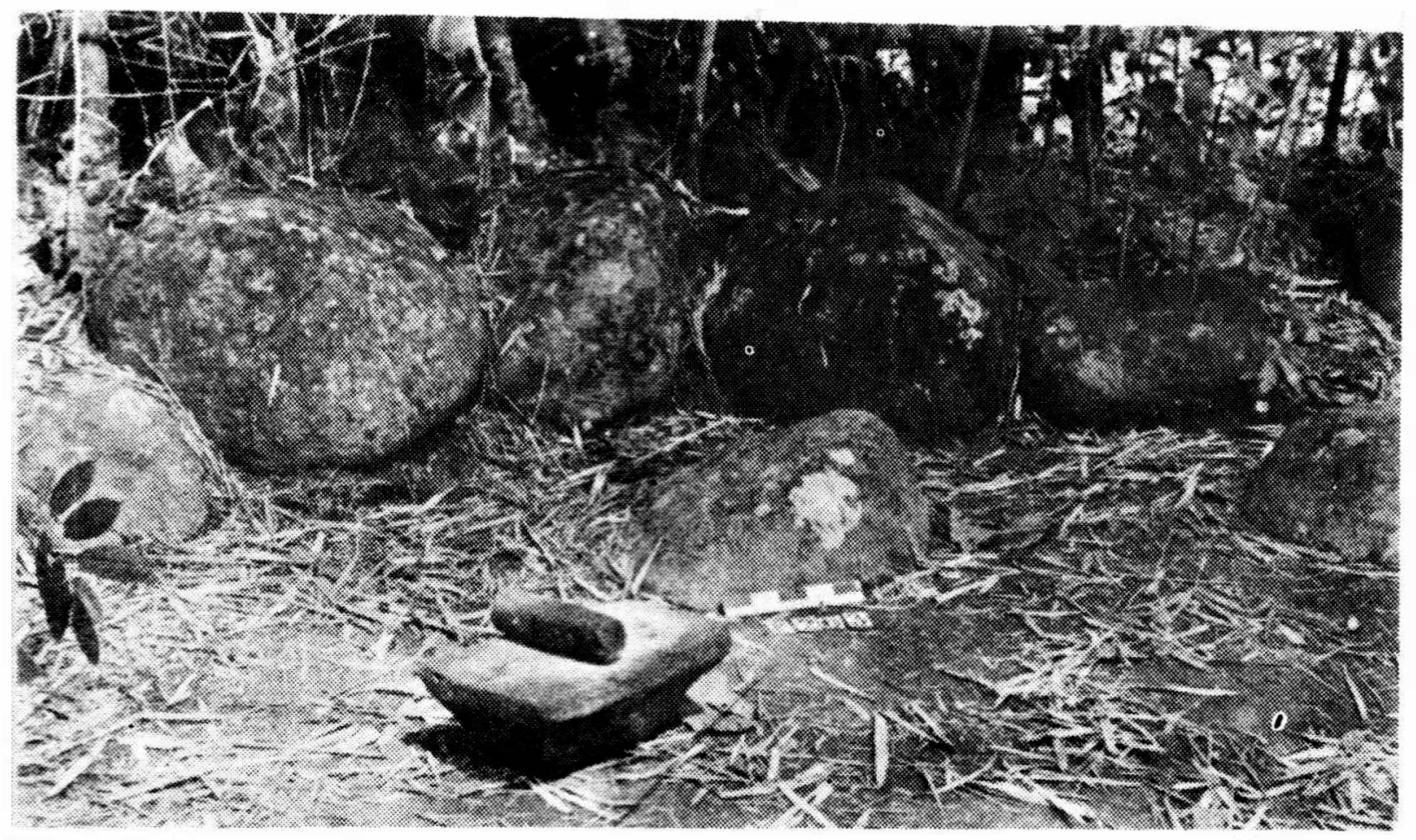

Foto no. 1:

Susunan batu setengah lingkaran serta sepasang piptsan dan gandik dilihat dari, Timur.

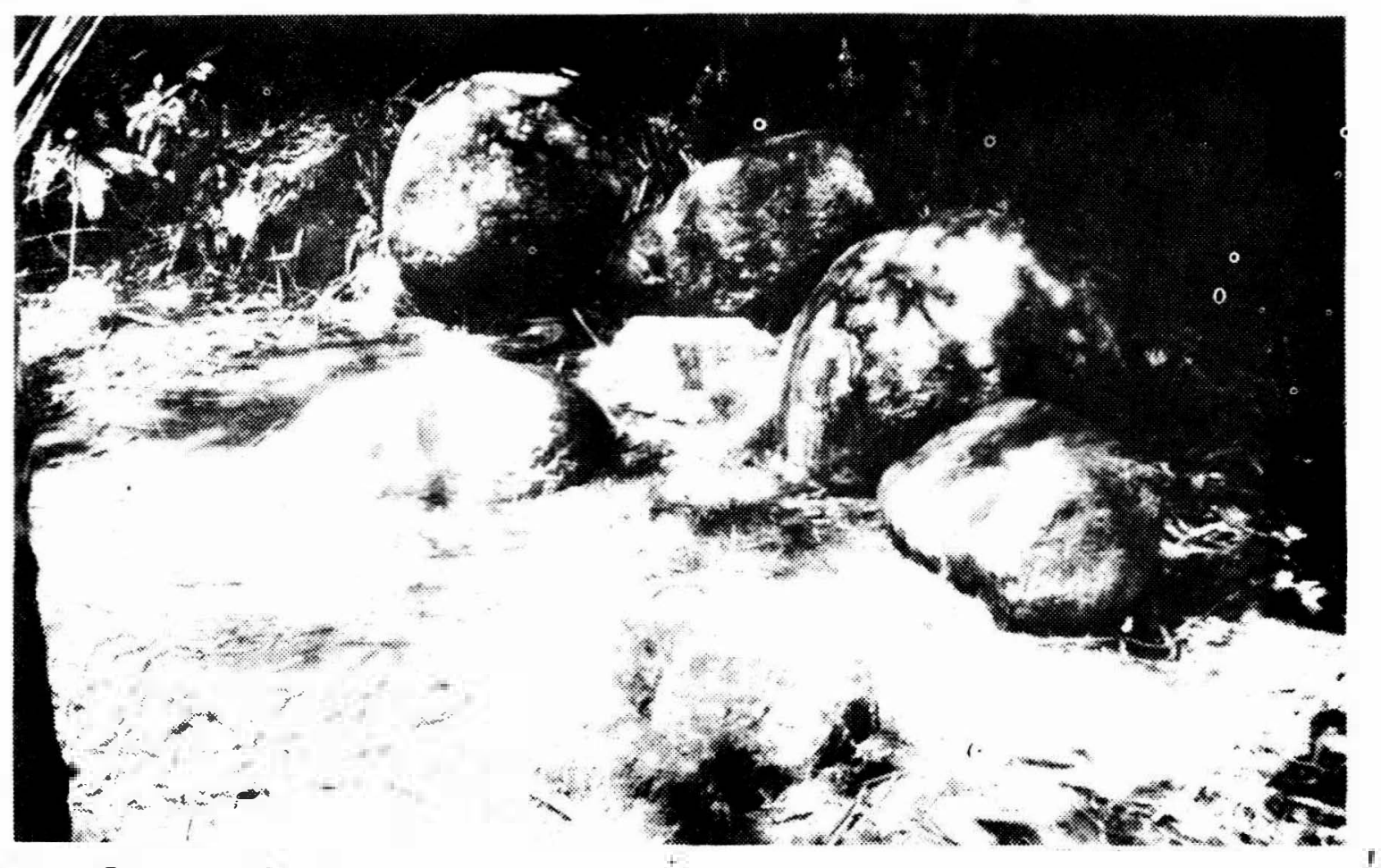

Foto no. 2:

Susunan batu setengah lingkaran dilihat dari Utara. 


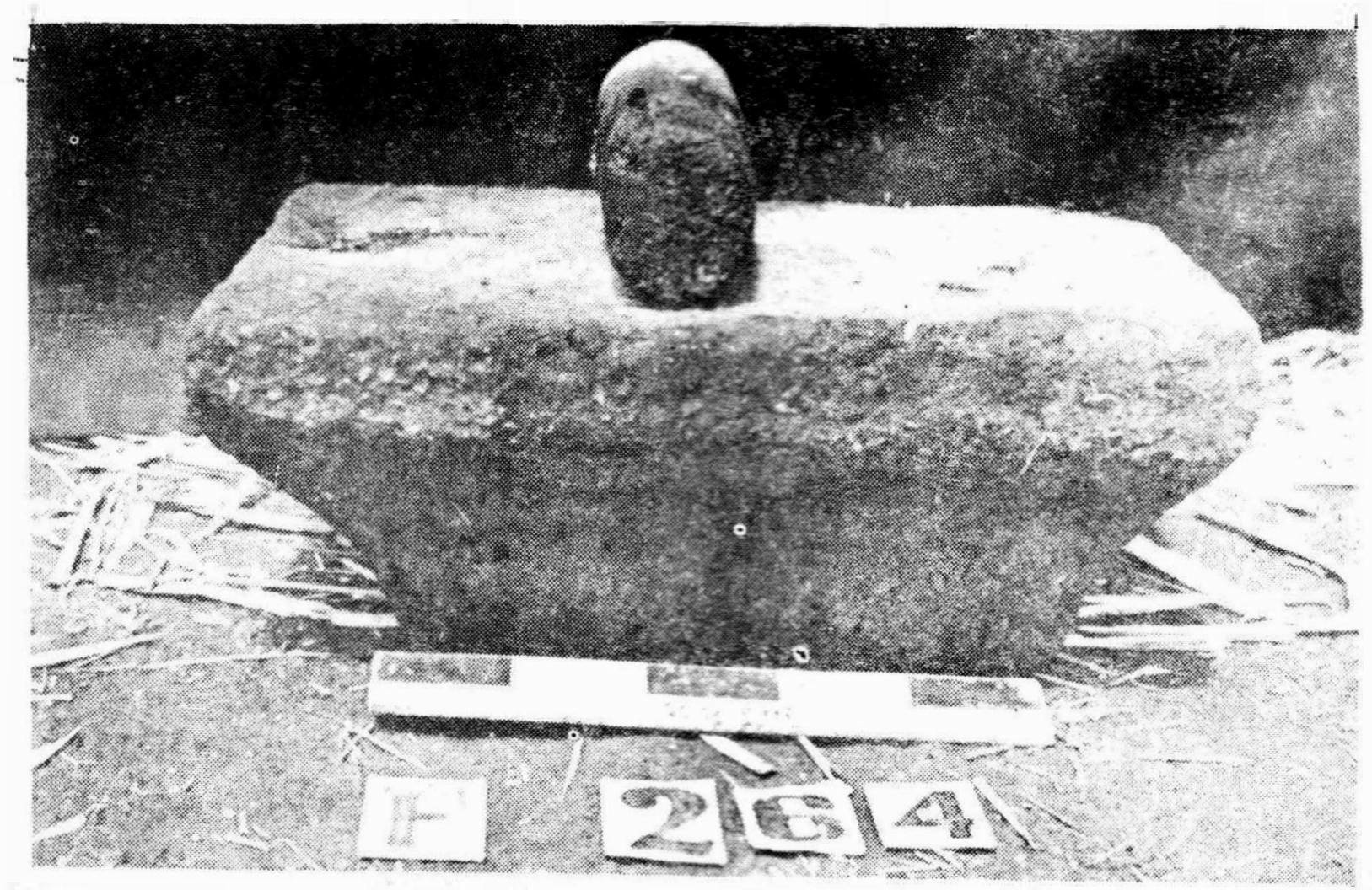

\section{Foto no. 3:}

Seposang batu pipisan dan gandik yang dtemukan di tomplets ausunan bartu berbentuk setengah lingkaran.

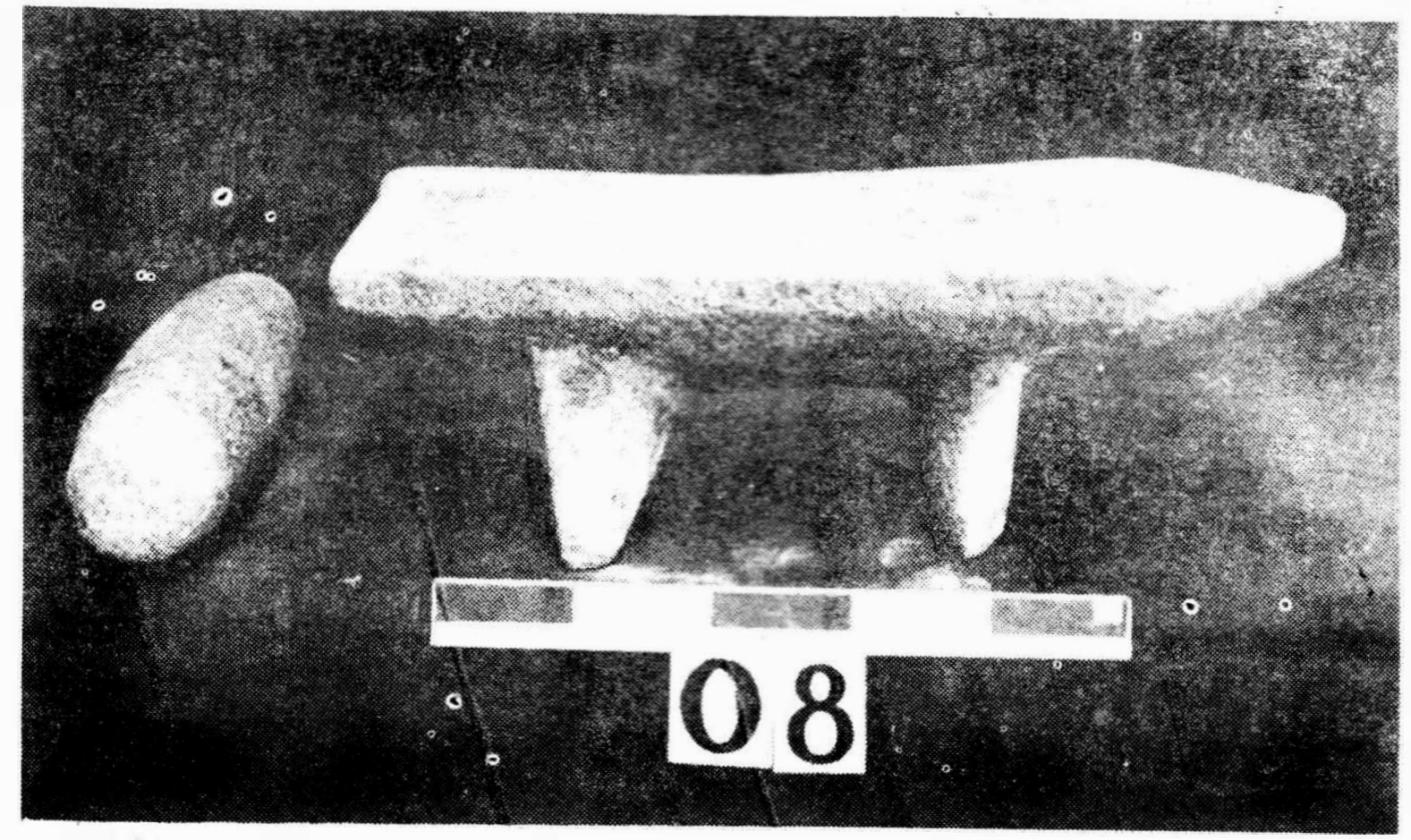

Foto no. 4:

Contoh sepasang batu pipisan dan gandik temuan dari daerah Sidomulyo, Salaman, Magelang. Koleksi Suaka Peninggalan Sejarah dan Purbakala Jawa Tengah di Prambanan. 